\title{
PENGARUH PEMBERIAN GEL EKSTRAK DAUN MELATI Uasminum sambac L. Ait) TERHADAP JUMLAH FIBROBLAS KULIT DALAM PENYEMBUHAN LUKA BAKAR DERAJAT II A PADA TIKUS PUTIH (Rattus norvegicus) GALUR WISTAR
}

\author{
Nurdiana ${ }^{1}$, Ikhda Ulya ${ }^{2}$, I Putu Ryan Aristya Putra ${ }^{3}$ \\ ${ }^{1}$ Laboratorium Farmakologi Fakultas Kedokteran Universitas Brawijaya \\ ${ }^{2}$ Program Studi Ilmu Keperawatan Fakultas Kedokteran Universitas Brawijaya \\ ${ }^{3}$ Mahasiswa Program Studi IImu Keperawatan Fakultas Kedokteran Universitas Brawijaya
}

\begin{abstract}
ABSTRAK
Luka bakar merupakan kasus yang sering ditemukan dalam kehidupan sehari-hari karena penggunaan sumber panas oleh masyarakat.Luka bakar derajat 2 merupakan kasus terbanyak di seluruh dunia.Penatalaksanaan luka bakar dengan menggunakan dressing atau obat topikal saat ini memiliki biaya yang relatif mahal.Daun melati memiliki kandungan saponin, tannin, dan flavonoid yang dapat membantu dalam penyembuhan luka.Tujuan dari penelitian ini adalah untuk mengetahui pengaruh pemberian krim ekstrak daun melati terhadap jumlah fibroblas kulit dalam penyembuhan luka bakar derajat II A pada tikus putih galur wistar.Jumlah fibroblas luka bakar derajat II A dihitung pada hari ke-15 dari perawatan luka. Penelitian ini menggunakan desain True-experiment dengan metode Post test Only Control Group Design. Penelitian ini menggunakan 5 kelompok yaitu NS 0,9\%, SSD 1\%, ekstrak daun melati konsentrasi 15\%, 30\%, dan $45 \%$. Uji One Way ANOVA menunjukkan hasil adanya perbedaan yang signifikan terhadap jumlah fibroblas antara kelompok NS 0,9\%, SSD 1\%, dosis ekstrak daun melati $15 \%, 30 \%$, dan $45 \%$ dengan $p$-value $(0,000)<\alpha(0,05)$. Hasil uji Post Hoc menunjukkan perbedaan yang signifikan antara NS $0,9 \%$ dengan ekstrak daun melati $45 \%$ dengan $p$-value $(0,000)<\alpha(0,05)$. Namun tidak ada perbedaan signifikan antara ekstrak daun melati $30 \%$ dengan ekstrak daun melati $45 \%$. Kesimpulan penelitian ini adalah ekstrak daun melati $45 \%$ mempunyai pengaruh yang lebih optimal pada luka dibandingkan NS 0,9\%, SSD 1\%, ekstrak daun melati 15\% dan 30\%. Diharapkan penelitian lebih lanjut terhadap uji toksisitas ekstrak daun melati.

Kata kunci :Ekstrak Daun Melati, Jumlah Fibroblas, Luka Bakar Derajat II A
\end{abstract}

\begin{abstract}
Burns happens in daily life because of thermal uses. Second degree burns is the most burns cases in whole world. Treatment of burns by using dressing or topical medications currently has a high cost. Jasmine leaves contain saponins, tannins, and flavonoids that can help in wound healing. The purpose of this study was to determine the effect of jasmine leaf extract gel on the number of dermal fibroblast in second-degree a burn wound healing on wistar strain white rat. The number of dermal fibroblast was calculated on the $15^{\text {th }}$ day of wound care. The experiment design of this study is True experiment with Post-test Only Control Group Design method. This study consist of 5 groups: NS 0,9\%, SSD 1\%, jasmine leaf extract 15\%, 30\%, and 45\%. One Way ANOVA test results showed significant differences in the number of dermal fibroblast between NS $0,9 \%$ group, SSD $1 \%$ group, jasmine extract group doses $15 \%, 30 \%$, and $45 \%$ with $p$-value $(0,000)<\alpha(0,05)$. Post hoc test results showed a significant differences between NS 0,9\% group with jasmine leaf extract 45\% with $p$-value $(0,000)<\alpha(0,05)$. But there was no significant difference between jasmine leaf extract $30 \%$ with jasmine leaf extract 45\%. Conclusion of this study is the $45 \%$ jasmine leaf extract have more optimal influence on burn wound than NS 0,9\%, SSD 1\%, jasmine leaf extract $15 \%$ and $30 \%$. It is expected a further research for toxicity test of jasmine leaf extract.
\end{abstract}

Key words :Jasmine Leaf Extract, Number of Dermal Fibroblast, Second-degree A Burn

Jurnal IImu Keperawatan, Vol: 4, No. 1 Mei 2016 ; Korespondensi : Ikhda Ulya,Jurusan Keperawatan Fakultas Kedokteran Universitas Brawijaya. Jl. Veteran Malang, kode pos 65145. Email : ikhdaulya@yahoo.comNo.Hp 081654979516 


\section{PENDAHULUAN}

Luka bakar (combustio) adalah kerusakan atau kehilangan jaringan akibat kontak dengan sumber panas seperti api, air panas, bahan kimia, listrik, dan radiasi (Moenadjat, 2009). Menurut Riset Kesehatan Dasar Depkes RI (2008), prevalensi kejadian luka bakar di Indonesia sebesar 2,2\%. American Burn Association (2012) menunjukkan bahwa sekitar $69 \%$ luka bakar terjadi di rumah, $9 \%$ di tempat kerja, $7 \%$ di jalan raya, $5 \%$ di tempat rekreasi, dan $10 \%$ lain-lain. Di antara tiga derajat klasifikasi luka bakar, luka bakar derajat 2 merupakan kasus terbanyak di seluruh dunia (Xiang Xu, 2004).

Luka bakar derajat II dikelompokkan menjadi dua, yaitu derajat II A dan derajat II B (dalam). Pada luka bakar derajat II A (dangkal), kerusakan mengenai bagian superfisial dari dermis. Penatalaksanaan luka bakar secara umum adalah menggunakan rendam normal saline (Nurdiana, et al., 2008). Saat ini telah banyak ditemukan obat-obatan untuk mempercepat proses penyembuhan luka bakar, seperti Silver sulfadiazine, Bacitracin dan Mafenide acetate (agen antimikrobial), atau Hydrocolloids dan Hydrogell sebagai Absorptive dressing (Singer dan Dagum, 2008).Pemakaian Silver sulfadiazine $1 \%$ (SSD $1 \%$ ) sudah menjadi standar pada pengobatan luka bakar (Widagdo,
2003).Biaya obat-obatan luka bakar modern saat ini relatif tidak murah, sehingga menyebabkan masyarakat mulai beralih menggunakan terapi berbasis herbal atau tanaman tradisional (Christiawan \& Perdanakusuma, 2012).

Daun Melati (Jasminum sambacL. Ait) merupakan salah satu alternatif obat herbal yang dapat digunakan untuk terapi luka bakar. Daun melati (Jasminum sambacL. Ait) dapat digunakan sebagai obat alternatif karena memiliki senyawa saponin, tanin, dan flavonoid yang berperan untuk pembentukan fibroblas. Saponin akan mengaktifkan fungsi dari TGF- $\beta$, vascular endothelial growth factor (VEGF), epidermal growth factor (EGF) dan fibroblast growth factor (FGF). TGF- $\beta$ dan FGF akan menstimulasi migrasi dan proliferasi fibroblas (Robin, 2007; Kimura, et al, 2006; Banso, et al, 2007). Semakin banyak fibroblas yang terbentuk maka akan mempercepat kontraksi luka dan akan mempercepat penyembuhan luka. Tanin merupakan polifenol yang memiliki kemampuan untuk menginduksi TGF- $\beta$ (Khan, et al, 2012). Tanin merupakan antioksidan yang juga menginduksi TGF- $\beta$ untuk proliferasi fibroblast. Tanin juga menginduksi limfokin untuk meningkatkan migrasi makrofag. Makrofag merangsang sekresi faktor pertumbuhan sehingga meningkatkan proliferasi fibroblast (Gurib-Fakim, 2006). 
Flavonoid juga berfungsi sebagai antioksidan dan antibakteri yang bisa meningkatkan aktivasi dan proliferasi fibroblas, sehingga memicu pembentukan kolagen dan mempercepat proses penyembuhan luka (Barbul, 2005).

Penelitian ini bertujuan untuk mengetahui apakah pemberian gel ekstrak daun melati (Jasminum sambac L. Ait) secara topikal pada luka bakar kulit derajat II A pada Tikus Putih (Rattus norvegicus) galur wistar dapat meningkatkan pembentukan fibroblas.

\section{METODE}

\section{Desain Penelitian}

Penelitian ini menggunakan desain true experimental laboratory dengan metode Randomized Posttest Only Controlled Group Design.Sampel diambil secara acak (simple random sampling) berjumlah 25 ekor tikus putih jantan dengan umur 2,5-3 bulan dan berat badan 150-200 gram kemudian dibagi menjadi 5 kelompok, yaitu kelompok kontrol pertama diberi NS 0,9\%, kelompok kontrol kedua diberi NS 0,9\% + SSD 1\% dan 3 kelompok perlakuan diberikan NS 0,9\% + gel ekstrak daun melati konsentrasi 15\%, 30\%, dan 45\%. Masingmasing kelompok berjumlah 5 ekor tikus.

Pembuatan Luka Bakar Derajat II A
Menempelkan sterofoam berbentuk balok dengan ukuran $2 \times 2 \mathrm{~cm}$ yang dilapisi dan dibungkus kassa steril dan dicelupkan ke dalam air panas $98^{\circ} \mathrm{C}$ selama 3 menit kemudian ditempelkan pada punggung tikus selama 30 detik yang sebelumnya dianestesi menggunakan lidokain non-adrenalin.

\section{Perawatan Luka Bakar Derajat II A}

Pada kelompok kontrol pertama luka dibersihkan dengan NS 0,9\% kemudian ditutup dengan kassa steril dan diplester, kelompok kontrol kedua dibersihkan dengan NS 0,9\% kemudian diberi SSD $1 \%$ kemudian ditutup dengan kassa steril dan diplester. Sedangkan pada kelompok perlakuan luka dibersihkan dengan NS 0,9\% kemudian diberikan gel ekstrak daun melati 15\%, 30\% dan $45 \%$ pada area luka kemudian luka ditutup dengan kassa steril dan diplester.

\section{Pembuatan Ekstrak Daun Melati}

Proses ekstrasi menggunakan 100 gram serbuk daun melati (Jasminum sambac L. Ait) kemudian direndam dengan etanol 96\% selama 3 hari, lalu dikocok selama 30 menit lalu dibiarkan selama 24 jam sampai mengendap. Ambil lapisan atas campuran etanol dengan zat aktif, masukkan ke dalam labu evaporasi 1 liter, isi water bath dengan air sampai penuh, kemudian pasang semua alat termasuk rotary evaporator, pemanas water bath (atur sampai 
$70-80^{\circ} \mathrm{C}$ ) lalu sambungkan dengan aliran listrik. Biarkan larutan etanol memisah dengan zat aktif.Tunggu sampai aliran etanol berhenti menetes pada labu penampung. Hasilnya kirakira $1 / 3$ dari serbuk daun melati.Lalu masukkan hasil ekstraksi ke dalam botol plastic dan simpan dalam freezer.

\section{Perhitungan Pencampuran Ekstak dengan} Vaseline

Ekstrak daun melati dicampurkan vaseline dengan menggunakan rumus:

$$
\mathbf{L}=\frac{\mathbf{a}}{\mathrm{b}} \times 100 \%
$$

\section{Keterangan :}

$\mathrm{L}$ : Konsentrasi larutan (\%)

a : Massa zat terlarut (mg)

b : Massa zat pelarut (mg)

Bila dimasukkan rumus penambahan vaselin seperti di atas didapatkan hasil sebagai berikut:

- Konsentrasi 15\%: 25,5 mg ekstrak etanol daun melati dalam $170 \mathrm{mg}$ vaselin

- Konsentrasi 30\%: 42 mg ekstrak etanol daun melati dalam $140 \mathrm{mg}$ vaselin.
- Konsentrasi 45\%: 49.5 mg ekstrak etanol daun melati dalam $110 \mathrm{mg}$ vaselin.

\section{Identifikasi Pembentukan Fibroblas Luka}

Kulit pasca luka bakar mencit diambilpada hari ke-15untuk dilakukan pemeriksaan histopatologis. Kulit mencit tersebut diperoleh setelah dilakukan anestesi dengan menggunakan Chlorofoam. Kulit yang sudah diambil difiksasi dalam larutan buffer formalin $10 \%$ untuk dilakukan pewarnaan hematoxylin eosine. Metode pengumpulan data dilakukan dengan penilaian mikroskopis. Pengamatan dilakukan terhadap jumlah fibroblas dan dibandingkan antara kelompok kontrol dan perlakuan, serta antar kelompok perlakuan (Wahyuda, et al., 2013).

Fibroblas adalah sel yang berbentuk gelendong, memiliki satu inti atau lebih, bersifat basofilik, dan berwarna ungu pada pewarnaan hematoxylin eosin pada saat dilakukan pengamatan.Fibroblas diamati di lapisan kulit dermis. Pengamatan mikroskopis dilakukan dengan menggunakan fotomikroskop OLYMPUS seri XC10 yang dilengkapi software OlyVIA (Viewer for Imaging Applications) dengan pembesaran 400x pada tiap lapang pandang. Lalu jumlah sel dilihat pada monitor dan dihitung secara manual. Jumah sel akan dinyatakan dalam satuan sel. 
Analisa Data

Uji normalitas data menggunakan uji ShapiroWilk terhadap jumlah sel fibroblas luka bakar derajat II A didapatkan p-value (nilai signifikansi) $>\alpha(0,05)$ yang menunjukan data berdistribusi normal. Uji homogenitas menggunakan uji Levene didapatkan hasil penghitungan jumlah sel fibroblas mendapatkan $p$-value (nilai signifikansi) $>\alpha$ $(0,05)$ yang menunjukan data memiliki keseragaman yang homogen. Uji one way anova diperoleh nilai signifikansi $0,000<\alpha$ $(0,05)$ artinya terdapat perbedaan yang signifikan minimal 1 pasang kelompok. Uji post hoct didapatkan hasil bahwa perbedaan rerata jumlah sel fibroblas luka bakar derajat II A antara kelompok A (NS 0,9\%) berbeda secara signifikan dengan kelompok D (NS 0,9\% + ekstrak daun melati 30\%) dengan p-value $(0.000)<\alpha(0.05)$ dan E (NS 0,9\% + ekstrak daun melati $45 \%)$ dengan $p$-value $(0.000)<\alpha(0.05)$. Kelompok B (NS 0,9\% + SSD 1\%) berbeda signifikan dengan kelompok C (NS 0,9\% + ekstrak daun melati 15\%) dengan $p$-value $(0.030)<\alpha(0.05)$ dan kelompok E (NS 0,9\%+ ekstrak daun melati 45\%) dengan p-value $(0.005)<\alpha(0.05)$. Kelompok A (NS 0,9\%) tidak berbeda signifikan dengan kelompok C (NS $0,9 \%+$ ekstrak daun melati $15 \%)$ dengan $p$ value $(0.920)<\alpha(0.05)$. Kelompok B (NS 0,9\%+ SSD 1\%) tidak berbeda signifikan dengan kelompok D (NS 0,9\% + ekstrak daun melati $30 \%)$ dengan $p$-value $(0.252)<\alpha(0.05)$.

\section{HASIL}

Perawatan luka bakar derajat II A dilakukan selama 14 hari, pada hari ke 15 tikus dimatikan dan dibuat slide histologi dan dilakukan penghitungan jumlah sel fibroblas seperti pada gambar 1.Penghitungan jumlah sel fibroblas pada irisan jaringan luka dilihat dengan fotomikroskop OLYMPUS seri XC10 yang dilengkapi software Olyvia (Viewer for Imaging Applications) dengan perbesaran 400 kali tiap lapang pandang.Penghitungan fibroblas diambil dari 15 lapang pandang kemudian dihitung reratanya. Hasil penghitungan jumlah fibroblas luka bakar derajat II A setelah diberikan gel ekstrak daun melati, SSD 1\% dan normal saline 0,9\% pada hari ke-15 dapat dilihat pada tabel 1.

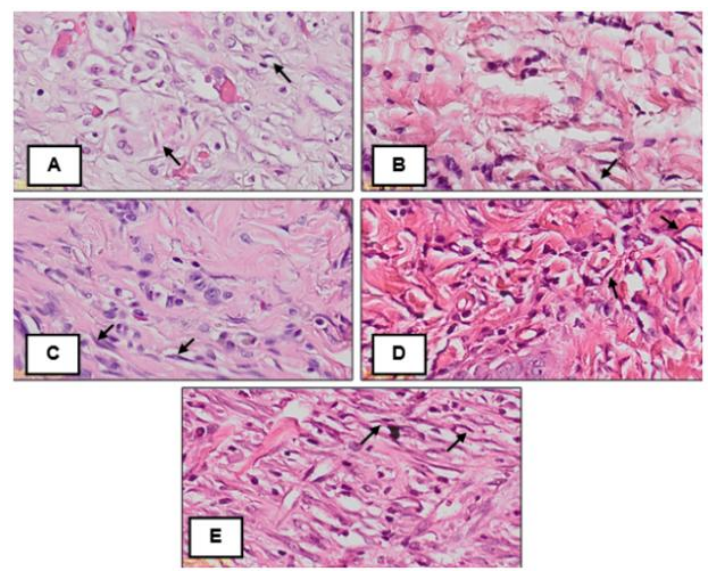

Gambar 1.Pengamatan Histologis Jumlah Fibroblas dengan Pengecatan H\&E pada Perbesaran 400x terhadap5 Kelompok. (A) NS 0,9\%, (B) NS 0,9\% + SSD $1 \%$, (C) NS 0,9\% + Ekstrak daun melati 15\% (D) NS 0,9\% + Ekstrak daun melati 30\%, (E) NS 0,9\% + Ekstrak daun melati $45 \%$. 
Tabel 1. Rerata jumlah Fibroblas pada Jaringan Kulit yang Terkena Luka Bakar Derajat II A pada Kelompok Kontrol dan Kelompok Perlakuan per Lapangan Pandang

\begin{tabular}{lc}
\hline \multicolumn{1}{c}{ Perlakuan } & $\begin{array}{c}\text { Rerata Jumlah } \\
\text { Fibroblas Tiap } \\
\text { Kelompok per } \\
\text { Lapang Pandang }\end{array}$ \\
\hline NS 0,9\% & $\mathbf{1 0 . 6 6}$ \\
\hline NS 0,9\%+ SSD 1\% & $\mathbf{1 2 . 2 2}$ \\
\hline NS 0,9\% + Ekstrak Daun & $\mathbf{1 0 . 9 8}$ \\
Melati Konsentrasi 15\% & \\
\hline NS 0,9\% + Ekstrak Daun & $\mathbf{1 3 . 0 3}$ \\
Melati Konsentrasi 30\% & \\
\hline NS 0,9\% + Ekstrak Daun & $\mathbf{1 3 . 7 8}$ \\
Melati Konsentrasi 45\% & \\
\hline
\end{tabular}

\section{PEMBAHASAN}

Fibroblas adalah sel predominan pulpa yang berfungsi sebagai pembuatan substansi dasar dan sintesis kolagen.Fibroblas merupakan sel yang paling umum ditemui pada jaringan ikat (Djuwita, et al., 2010). Fibroblas memiliki peran besar dalam proses proliferasi (Perdanakusuma, 2007). Sel fibroblas tersebar sepanjang berkas serat kolagen dan berbentuk gelendong dengan ujung yang meruncing, memiliki satu inti atau lebih, bersifat basofilik dan tercat ungu dengan pewarnaan hematoksilin eosin (Bloom dan Fawcet, 2002).Proses penyembuhan luka yang baik adalah salah satunya ditandai dengan peningkatan jumlah fibroblast (Saunders, 2007). Pada tabel
1 kelompok perlakuan menggunakan NS 0,9\%+ ekstrak daun melati $45 \%$ mempunyai rata-rata jumlah fibroblas luka bakar derajat II A yang paling besar $(\bar{x}=13,78)$. Setelah kelompok perlakuan NS 0,9\% + ekstrak daun melati 45\%, kelompok yang memiliki rata-rata jumlah fibroblast terbesar ke-2 adalah kelompok perlakuan NS 0,9\% + ekstrak daun melati 30\% ( $\bar{x}=13,03)$. Kemudian disusul oleh kelompok kontrol NS $0,9 \%+\operatorname{SSD} 1 \% \quad(\bar{x}=12,22)$, kelompok perlakuan NS 0,9\% + ekstrak daun melati $15 \%(\bar{x}=10,98)$ dan terakhir kelompok kontrol NS $0,9 \%(\bar{x}=10,66)$.

Berdasarkan penelitian yang telah dilakukan hasil uji One Way ANOVA terhadap ekstrak daun melati $15 \%$, 30\% dan 45\% menghasilkan p-value $(0,000)<\alpha(0,05)$. Sehingga dapat dikatakan bahwa ekstrak daun melati 15\%, 30\% dan $45 \%$ mempunyai efek yang signifikan terhadap peningkatan jumlah fibroblas luka bakar derajat II A. Setelah dilakukan uji perbandingan berganda rata-rata jumlah fibroblas luka didapatkan kelompok kontrol menggunakan NS 0,9\% berbeda signifikan dengan kelompok kontrol menggunakan NS $0,9 \%+\operatorname{SSD} 1 \%$ dengan $p$-value $(0,005)<\alpha$ $(0,05)$, kelompok perlakuan ekstrak daun melati $30 \%$ dengan $p$-value $(0,000)<\alpha(0,05)$, dan NS $0,9 \%$ + ekstrak daun melati $45 \%$ dengan $p$-value $(0,000)<\alpha(0,05)$. 
Digunakannya ekstrak daun melati dalam penelitian ini untuk merawat luka karena daun melati mengandung saponin,tanin dan flavonoid.Mekanisme saponin adalah sebagai immunomodulator, yaitu meningkatkan produksi dan migrasi makrofag ke daerah luka sehingga meningkatkan sekresi sitokin IL-1 $\beta$, dan meningkatkan proliferasi fibroblas pada daerah luka.Selain itu saponin juga berperan dalam mengaktifkan fungsi dari TGF$\beta . S a p o n i n a k a n$ meningkatkan ekspresi TGF- $\beta$. TGF- $\beta$ akan menstimulasi migrasi dan proliferasi fibroblas (Robin, 2007). Saponin juga menginduksi growth factor seperti vascular endothelial growth factor (VEGF), epidermal growth factor (EGF) dan fibroblast growth factor (FGF) (Kimura, et al, 2006; Banso, et al, 2007). Peningkatan FGF akan meningkatkan proliferasifibroblas. Peningkatan proliferasi fibroblas akan

mempercepat proses penyembuhan luka.

Tanin memiliki fungsi sebagai antioksidan dan antibakterial yang kuat, serta meningkatkan vaskularisasi dan proliferasi fibroblas.Tanin memiliki kemampuan untuk menginduksi TGF$\beta$, di mana nanti TGF- $\beta$ akan memicu migrasi dan proliferasi fibroblast (Khan, et al, 2012). Flavonoid diketahui memiliki fungsi mengurangi proksidasi lemak sehingga meningkatkan kelangsungan serat kolagen dan mencegah kerusakan sel(Getie, 2002; Shetty, 2008). Selain itu flavonoid juga memiliki efek antimikrobial dan astringen, yang mana berperan dalam kontraksi luka dan epitelisasi.Flavonoid dapat meningkatkan produksi fibroblas sehingga meningkatkan sintesis kolagen, dan meningkatkan difusi oksigen ke sel(Inan, et al., 2006).

Penggunaan SSD $1 \%$ sebagai kontrol pada penelitian ini karena SSD $1 \%$ merupakan standar pada pengobatan luka bakar derajat II A (Widagdo, 2004).Setelah diamati pada gambaran histopatologi kelompok kontrol SSD $1 \%$ tidak terlihat jaringan nekrotik, karena krim SSD $1 \%$ diketahui memiliki sifat bakteriostatik dan memiliki daya tembus yang cukup efektif terhadap semua kuman dan aman digunakan.Luka bakar merupakan tempat ideal bagi pertumbuhan mikroorganisme, serum dan debris menyediakan nutrien, dan cidera luka bakar itu sendiri menyebabkan gangguan aliran darah sehingga respons peradangan tidak efektif.Dengan pemberian SSD $1 \%$ dapat menghindarkan kulit dari infeksi (Nugraha dan Muhartono, 2013).

Normal salin digunakan sebagai kontrol dalam penelitian ini karena secara umum penatalaksanaan luka bakar menggunakan rendam normal salin (Nurdiana et al, 2008).Normal Salin yang mempunyai sifat moist dapat membantu proses pembentukan 
pembuluh darah yang baru lebih cepat sehingga dapat meningkatkan proses oksigenasi jaringan dan suplai nutrisi yang banyak (Imansyah, 2013). Peningkatan proses oksigenasi jaringan dan suplai nutrisi ke jaringan yang mengalami kerusakan akan menyebabkan proses epitelisasi jaringan yang lebih cepat sehingga meningkatkan kontraksi luka lebih cepat karena proses penyembuhan luka terjadi secara simultan (Imansyah, 2013). Selain itu normal salin merupakan cairan isotonis yang sering digunakan di rumah sakit sebagai perawatan konvensional untuk perawatan irigasi luka, pembersihan luka, dan hidrasi luka (Alexander, 2010). Walaupun normal salin sering digunakan untuk perawatan luka dan aman bagi tubuh, normal salin 0,9\% tidak memilki kandungan antimikroba seperti silver sulfadiazine dan ekstrak daun melati sehingga kemungkinan terjadinya infeksi lebih besar pada kelompok kontrol menggunakan NS 0,9\% (Linfors, 2004). Pada semua sampel kelompok kontrol yang dirawat hanya menggunakan NS 0,9\% di hari ke-15 masih terlihat jaringan nekrotik.

Hasil penelitian menunjukan kelompok perlakuan dengan ekstrak daun melati $45 \%$ menghasilkan rata-rata jumlah fibroblast luka bakar derajat II A yang paling baik seperti yang ditunjukan pada table 1. Hasil Post Hoc Test menunjukkan adanya perbedaan signifikan antara kelompok kontrol NS 0,9\% dibandingkan dengan kelompok perlakuan menggunakan NS 0,9\% + ekstrak daun melati 30\% dan 45\%, serta antara kelompok kontrol NS 0,9\% + SSD $1 \%$ dengan kelompok perlakuan menggunakan NS $0,9 \%$ + ekstrak daun melati 15\% dan 45\%. Disini bisa dilihat efektifitas ekstrak daun melati dalam peningkatan jumlah fibroblast luka bakar derajat II A. Ekstrak daun melati cukup efektif dalam peningkatan jumlah fibroblast luka karena memiliki kandungan senyawa saponin, tanin dan flavonoid. Metode pengeringan daun melati yang menggunakan cara dianginanginkan dalam ruangan dengan suhu kamar membuat kandungan senyawa saponin, tanin dan flavonoid pada ekstrak tetap tinggi. Pengeringan daun dengan cara dianginanginkan memiliki kandungan saponin, tanin, dan flavonoid yang jauh lebih tinggi daripada pengeringan menggunakan oven ataupun dijemur dibawah sinar matahari langsung (Widiyastuti et al, 2009).

Tidak ada perbedaan signifikan antara kelompok kontrol NS 0,9\% dengan kelompok perlakuan menggunakan NS 0,9\% + ekstrak daun melati $15 \%$ dan antara kelompok kontrol NS $0,9 \%+$ SSD $1 \%$ dengan kelompok perlakuan menggunakan NS 0,9\% + ekstrak daun melati $30 \%$. Tidak ada perbedaan signifikan tersebut menunjukkan bahwa ekstrak daun melati 15\% dan $30 \%$ memiliki pengaruh yang sama 
terhadap peningkatan jumlah fibroblas luka bakar derajat II A. Hasil penelitian ini menunjukkan bahwa terdapat pengaruh ekstrak daun melati terhadap jumlah fibroblas dalam penyembuhan luka bakar derajat II A.

\section{KESIMPULAN}

1. Pemberian sediaan gel ekstrak daun melati (Jasminum sambacL. Ait) secara topikal pada luka bakar kulit derajat II A pada tikus putih (Rattus norvegicus) galur wistar dapat meningkatkan pembentukan fibroblas.

2. Pada perawatan luka bakar derajat II A pada kelompok kontrol menggunakan Normal Saline 0,9\% ( $\mathrm{NaCl} 0,9 \%)$, didapatkan jumlah fibroblas 10,66 per lapang pandang.

3. Pada perawatan luka bakar derajat II A pada kelompok kontrol menggunakan Normal Saline 0,9\% ( $\mathrm{NaCl} 0,9 \%)+$ Silver Sulfadiazine 1\% (SSD 1\%), didapatkan jumlah fibroblas 12,22 per lapang pandang.

4. Pada perawatan luka bakar derajat II A pada kelompok kontrol menggunakan Normal Saline 0,9\% ( $\mathrm{NaCl} 0,9 \%)+$ Ekstrak Daun Melati $15 \%$, didapatkan jumlah fibroblas 10,98 per lapang pandang.

5. Pada perawatan luka bakar derajat II A pada kelompok kontrol menggunakan Normal Saline 0,9\% $(\mathrm{NaCl}$ 0,9\%) + Ekstrak Daun Melati 30\%, didapatkan jumlah fibroblas 13,03 per lapang pandang.

6. Pada perawatan luka bakar derajat II A pada kelompok kontrol menggunakan Normal
Saline 0,9\% $(\mathrm{NaCl} 0,9 \%)+$ Ekstrak Daun Melati $45 \%$, didapatkan jumlah fibroblas 13,78 per lapang pandang.

7. Hasil Uji One Way ANOVA didapatkan hasil signifikansi $0,000<\alpha(0,05)$, yang artinya pemberian ekstrak daun melati konsentrasi $15 \%$, 30\%, dan $45 \%$ memberikan pengaruh yang signifikan terhadap jumlah sel fibroblas luka bakar derajat II A.

\section{SARAN}

1. Diperlukan penelitian lebih lanjut untuk menentukan dosis optimum penggunaan ekstrak daun melati untuk perawatan luka bakar derajat II A

2. Diperlukan penelitian lebih lanjut terhadap uji toksisitas ekstrak daun melati sehingga dapat digunakan untuk perawatan luka bakar derajat II A secara aman di masa mendatang.

3. Untuk penelitian selanjutnya diperlukan pengawasan balutan kassa yang lebih baik pada perawatan luka bakar derajat II A secara topikal dengan balutan tertutup untuk mempercepat penyembuhan luka bakar derajat II A.

4. Diperlukan penelitian lebih lanjut untuk mengetahui tingkat kadar kandungan masing-masing senyawa kimia dalam daun melati

www.jik.ub.ac.id 


\section{DAFTAR PUSTAKA}

Alexander, Hepzibha. 2010. Heparin Versus

Normal Saline as a Flush Solution. International Journal for The Advancement of Science and Arts. No. 1.Issues 1.

American Burn Association Burn National Burn Repository. 2012. (http://www.ameriburn.org/resources_f actsheet.php, diakses 8 Mei 2013).

Barbul A. 2005. Wound Healing. In: F. Charles Brunicardi, Dana K., Andersen, Timothy R., Billiar, David L., et al., eds. Schwartz's principles of surgery. 8th ed. New York: McGraw-Hill Companies

Bloom William, Don W. Fawcett. 2002. Buku ajar histologi. Edisi 12. Terjemahan Jan Tambayong. Jakarta: EGC

Christiawan, A., Perdanakusuma, D.S. 2012. Antimicrobial Activity of Binahong Leaves Toward Pseudomonas Aeruginosa and Staphylococcus Aureus which Often Becomes a Complication af Burns Wound Healing.Jurnal Rekonstruksi dan Estetik, 1 (1).

I,Djuwita., Harystiarini, T.Widyaputri, A. Efendi., E.M Kaiin, dan Nurhidayat. Tingkat Pertumbuhan dan Analisa Protein SelSel Fibroblas Fetal Tikus Hasil Kultur In
Vitro. Majalah IImu Kehewanan Indonesia. 2010, 1(2): 9-16

Getie, M., Gebre, M.T., Reitz, R., Neubert, R.H. Evaluation of the release profiles of flavonoids from topical formulations of the crude extract of the leaves of Dodonea viscosa (Sapindaceae) Pharmazie. 2002; 57: 320-322.

Gurib-Fakim, A. Medicinal Plants: Traditions of Yesterday and Drugs of Tomorrow. Mol Aspects Med, 2008; 27 (1): 1-93.

Imansyah, Bayu Aldi. 2013. Pengaruh Pemberian Ekstrak Daun Sirih (Piper betle L) Terhadap Peningkatan Kontraksi Luka Fase Proliferasi Pada Perawatan Luka Bakar Derajat IIA Pada Tikus Putih (Rattus norvegicus) Galur Wistar. Tugas Akhir. Tidak Diterbitkan. Fakultas Kedokteran Universitas Brawijaya.

Inan, A., Sen, M., Koca, C., Akpinar, A., Dener, C.The Effect of Purified Micronized Flavonoid Fraction on The Healing of Anastomoses in The Colon in Rats. Surg Today. 2006; 36: 818-822.

Khan, I., Kumar, N., Pant, I., Narra, S., Kondaiah, P. 2012. Activation of TGF-bPathway by Areca Nut Constituents: A Possible Cause of Oral Submucous Fibrosis. PLoS ONE. 7(12): 1-12. 
Kimura, Y., Sumiyoshi, M., Kawahira, K., Sakanaka, M. 2006.Effects of Ginseng Saponins Isolated from Red Ginseng Roots on Burn Wound Healing in Mice. Br. J. Pharmacol. 148(6): 860-870.

Lindfors, Julie. 2004. A Comparison of an Antimicrobial Wund Cleanser to Normal Saline in Reduction of Bioburden and its Effect on Wound Healing. Ostomy/Wound Management. 50 (8): 28-41.

Moenadjat, Yefta. 2009. Luka Bakar: Masalah dan Tatalaksana. Jakarta: Balai Penerbit FKUI.

Nurdiana, et al. 2008.Perbedaan Kecepatan Penyembuhan Luka Bakar Derajat II Antara Perawatan Luka Menggunakan Virgin Coconut Oil (Cococ Nucifera) Dan Normal Salin pada Tikus Putih (Rattus Novergicus) Strain Wistar. Fakultas Kedokteran Univesitas Brawijaya.

Perdanakusuma, D.S. 2007. Anatomi Fisiologi Kulit dan Penyembuhan Luka.Makalah disajikan dalam Seminar Pelatihan Luka Bakar, JW Marriot Hotel Surabaya, 5 September.

Robbin. 2007. Buku Ajar Patologi. Volume 1. Jakarta: EGC.
Shetty, S., Udupa, S., Udupa L. Evaluation of antioxidant and wound healing effectsof alcoholic and aqueous extract of Ocimum sanctum Linn in rats. EvidenceBased Complementary and Alternative Medicine. 2008;5(1):95-101.

Singer, A.J. \& Dagum, A.B.Current Management of Acute Cutaneous Wounds. N Engl J Med, 2008; 359 (10): 1037-46.

Wahyuda, et al., 2013.Tingkat Kepadatan Fibroblas pada Luka Sayat Mencit dengan Pemberian Gel Lidah Buaya (Aloe chinensis Baker).Education of Medical University of Riau 2013.

Widagdo, Tri Djoko. 2004. Perbandingan Pemakaian Aloe Vera 30\%, 40\%, dan Silver Sulfadiazine 1\% Topikal pada Penyembuhan Luka Bakar Derajat II. Laporan Penelitian. Fakultas Kedokteran Universitas Diponegoro.

Widyastuti, Yuli et al. 2009. Pengaruh Cara Pengeringan Terhadap Perubahan Fisikokimia Daun Kumis Kucing (Orthosipon stamineus Benth).Jurnal Tumbuhan Obat Indonesia.Vol. 2.No. 1.

Xu, Rong Xiang. 2004. Burns Regenerative Medicine and Theraphy. Switzerland: S. Karger AG. 